\title{
ONLINE-LEARNING PROGRAM TO DEVELOP LEADERSHIP ON STUDENT COUNCIL ORGANISATION
}

\author{
Tine YULIANTINI ${ }^{1}$, Daru ASIH ${ }^{2}$, Achmad SUDIRO ${ }^{3}$, Intan APRIADI ${ }^{4}$, Agung YUNIARINTO5, \\ Jazuli SURYADHI ${ }^{6}$, and Deden KURNIAWAN* \\ 1,2,3,6,7 Universitas Mercu Buana \\ ${ }^{4,5}$ Universitas Brawijaya University \\ soelton@mercubuana.ac.id
}

\begin{abstract}
The COVID-19 pandemic is a global pandemic that disturbs all levels of society around the world. All segments of human life on earth are disturbed, without exception education. Many countries have decided to close schools, colleges and universities, including Indonesia in an effort to break the chain of spreading Covid-19. The teaching and learning process is carried out independently online and avoids face to face. Student Council Organization (OSIS) is a means of developing student interests and talents in the internal school environment. The existence of OSIS is very beneficial for schools and the community. OSIS is also a major component of the pilot school for development in that school. The problem is, many student councils do not show their existence as a driving force in the development of schools and students. The vacancy of OSIS activities is more due to the COVID-19 pandemic and also the low understanding of management and leadership concepts, so that prospective members cannot be managed properly. This community service activity is carried out by providing online training and program assistance for 1 month on building character leadership. The result of this activity is the increasing existence of OSIS in schools and benefits for students and the community as a forum for forming leadership character and improving OSIS organizational management capabilities and contributing to human development.
\end{abstract}

Keywords: Building Character, Human Development, Management, Leadership

\section{BACKGROUND}

The COVID-19 pandemic is A global pandemic, where disturbing all levels of society in all over the world. All segments of life humans on earth are disturbed, without exception education. Many countries decide closing schools, colleges as well as universities, including Indonesia as an effort to break the chain of the spread of Covid-19. The teaching and learning process is carried out independently online and avoid face-to-face.

Ministry of Education and Culture (Kemendikbud) issued Circular No 36962/MPK.A/HK/2020 regarding online learning (in network) and offline (outside network) to do work from home work from home in order Covid-19 prevention for educators and for students to all levels of education throughout Indonesia. To cut off the spread of Covid-19 and comply government regulations, educators and all students are forced not to be face to face temporarily. This condition is actually no readiness and maturity for all parties is good teachers, parents, students, network, internet, learning materials, moreover the condition of every village and even the city is different students, teachers up to the government. The impact of Covid-19 is also profound affect student activities or student organizations, namely Student Organization activities (OSIS). As isCovid-19 all organizational activities in some schools it is even hampered not a bit omitted. Therefore there needs to be a strategy to overcome the impact of covid-19 for student council activities.

The focus of this research is to describe how student council activities in SMA Jakarta Barat during the pandemic can be controlled, where the organization becomes a media for fostering and developing student productivity in organizations that foster leadership character, discipline, skills and creativity. In addition, this research is to motivate schools to be able to carry out OSIS activities and also provide an overview of strategies in carrying out the OSIS work program. However, with the Covid-19 pandemic, the role of the OSIS function is not running optimally, from basic activities to large activities, whether it goes according to plan or has to divert activities, or even eliminate these activities because not a few schools are really disrupted with Covid-19 and how an organization's strategy is to survive in the midst of a pandemic

The results of the survey and analysis conducted by researchers through the Monitoring and Evaluation of Distance Learning (Monev PJJ) activities in schools, several main factors became obstacles in implementing online learning using technology including: 1) Mastery of technology, 2) Limited facilities infrastructure, 3) Internet network, and 4) Financing. Covid-19 is also one of the obstacles felt by organizations in schools, because of the limited space for movement and activities that do not normally have many agendas that have to be postponed until canceled, which greatly impacts the life of school organizations.

Students are part of the young generation of Indonesia. Students get a huge opportunity to develop themselves as human beings with quality and integrity. Students as educated people are young intellectuals who are expected to have high creativity both in the academic and non-academic fields. In the development process, students are the power of human development which must be built at the same time so that they are capable of realizing a good future.

On the other hand, students also spearhead change of course there is in the generation of students who are educated like students at the upper secondary level (high 
school and MA). However, a paradox occurs, students who should be the spearhead of change in the positive direction, it is far from the desired expectations. If we ask parents, the right labels for students today are those who are not ready to be entrusted with trust be a leader. This certainly has a reason, where students are now closer to drugs, free sex, relationships that are not positive, and all negative behaviors attached to them.

Students who later become agents of change and social control agents are pioneers and milestones of a social development and change. Students who have an understanding of leadership are expected to be able to become the nation's successors who change the face of the world later. Students are also identified with scholars who are able to think critically of all existing problems. Students are also closely related to organization and skills. Skills are something that students should master from an early age to be able to carry out their functions in life and organize properly

The purpose of this study is to provide insight into leadership as well as provide experience to other schools to exchange information so that they can be more synergistic in developing leadership in various student organization activities even during the pandemic.

According Arief, H., Soelton, M., Rohman, F., \& Ritonga, R. (2019); The problems of the current student council management are: First, the lack of student council management understanding to manage intra-school organizations. Secondly, there is no process of leadership regeneration at the school level carried out simultaneously or continuously. Third, there is a decrease in the level of activity of the management which can be seen from the low percentage of activities carried out each year.

Ericha Windhiyana (2020) with a journal entitled The Impact of Covid-19 on online learning activities in a Christian university in Indonesia. The results of her research, in the field of education, the learning model changed drastically; all learning activities are carried out online starting from the elementary school level to the university level. Based on the results of interviews, online learning activities at this university run effectively by utilizing the Zoom, Google Classroom, Schoology, and Edmodo applications. Obstacles in carrying out online learning are mostly the problem of an internet connection that is less supportive.

According to Roya (2014), organization is a form of human union to achieve a common goal. However, we need to understand that the basis of the organization is not "who" but "what" which means that it is not the person who will hold the organization that matters. but the "what" is the task of the organization.

"Organizational performance is the totality of the work achieved by an organization achieving the goals of the organization means that, the performance of an organization can be seen from the degree to which the organization can achieve goals based on the goals set previously". Pieter (2015) According to Yousef (2012) Organizational performance is something that has been achieved by the organization within a certain period of time, both related to input, output, outcome, benefit, and impact.

Understanding Character Building in terms of language, Character Building or character building consists of two syllables, namely to build (to build) and character (character) which means to build which has the nature of repairing, fostering, establishing. While character is the character, character, morals or manners that distinguish one person from another. So Character Building is an effort to build and shape one's character and character to be good (Megawati, 2004). In building individual character, good behavior is needed in order to carry out organizational activities, both in government organizations and private organizations in society.

Character is something that is very important in the development of human quality, so character has the meaning of a fundamental value to influence all thoughts, actions and actions of every human being in the life of society, nation and state. A strong character attitude is able to optimize activities to achieve success and skills in realizing ideals so that they can take advantage of every opportunity that exists. The character of success is working hard to achieve something you want, never complaining no matter what the risks are. For the next few years what is needed are people who have good character (Agustian, 2001). Building character is not as easy as building houses, bridges, roads, and others because building character is a form of the essence of a person's soul that continues to be better and nobler, building character has many components that must be involved in educational institutions, parents and the community so that it runs ideally. with shared hope. Self-discipline is the most important thing in every effort to build and shape one's character because character implies: a positive quality that a person possesses, which makes him attractive and attractive, one's reputation and someone who is unusual or has an eccentric personality.

One of the values contained in the formation of building character is the ability to think logically, critically, creative, and innovative. If the ability to think logically, critically, creative, and innovative, it can be directed to conduct Experiential Learning-based training. In this activity

The concept of leadership has been offered by many authors in the field of organization and management. Leadership, of course, connects the individual aspects of a leader with the context of the situation in which the leader applies leadership. Leadership also has a collective nature in the sense that any behavior adopted by a leader will have a broad impact not on himself but on all members of the organization. The leader refers to a specific person or individual or noun. Meanwhile, leadership is the nature of the application of influence by a group member or organization to other members in order to encourage the 
group or organization to achieve its goals, Lussier, (2010). The role of the leader in the organization is one of the most important employee job satisfaction factors. The leader must be able to set goals, plan, organize, move and control all the resources they have. Leadership is the main thing in management which plays an important and strategic role for the survival of a company. Effective leadership can help organizations to survive in a situation of uncertainty in the future will come (Desianty, 2005).

Robbins and Judge (2015) leaders are people who have the task to direct and guide subordinates and are able to get subordinate support so that they can move subordinates towards achieving organizational goals. Leadership is the ability to influence a group towards achieving a vision or set goals.

For this reason, we need an activity that can train and guide students to become leaders who are smart, have character, have a vision of the future and have integrity. This activity is aimed at the board of senior high school student council in Kembangan, because the Intra-School Student Organization is a moment to reflect the commitment of change made by the educated generation in the midst of the scientific community, as well as contributing change towards a new generation of great and dignified Indonesia, then through generations young people who have an understanding of leadership in organizational management can all be realized.

Practicing leadership from an early age is a manifestation of national leadership going forward. At the discourse level, this training also aims to elevate the moral and moral perspective of a religious leader to build a new visionary, integrity, dynamic and civilized leadership. Furthermore, at the (practical) movement level, it is scheduled to carry a moral call for concern for the problems of the people and nation.

\section{METHOD}

This community service activity is carried out by providing online learning and program assistance for 1 month on building character leadership. The result of this activity is the increasing existence of OSIS in schools and benefits for students and the community as a forum for forming leadership character and improving OSIS organizational management capabilities and contributing to human development.

The learning is online using video conference (Zoom and Google meet) and uses experiential learning methods with interactive communication techniques via video conference, dialogues, discussions, role plays/ games, where participants are introduced to concepts, then directly involved with feelings, experiences, discussing the process and results of this learning to arouse the spirit of organizational performance

Learning is carried out online using video conferencing (Zoom and Google meet) and using the experiential learning method with interactive communication techniques through video conferencing, dialogue, discussion, role play / games, where participants are introduced about building character and values and ability to think logically, critically, creative, and innovative.

Learning is carried out online using video conferencing (Zoom and Google meet) and using the experiential learning method with interactive communication techniques through video conferencing, dialogue, discussion, role play / games, where participants are introduced about Human Resource and Human Development.

Learning is carried out online using video conferencing (Zoom and Google meet) and using the experiential learning method with interactive communication techniques through video conferencing, dialogue, discussion, role play / games, where participants are introduced about leadership among students.

Learning is carried out online using video conferencing (Zoom and Google meet) and using the experiential learning method with interactive communication techniques through video conferencing, dialogue, discussion, role play / games, where participants are introduced about Management especially for administrators of Student Council Organizations.

This online learning was held in collaboration with the Faculty of Economics and Business, Mercu Buana University (UMB) with Student Council organizations located in the West Jakarta area district Kembangan. UMB helped provide speakers, webinar flyers, pre-post examinations, evaluations, while the school helped send representatives of OSIS members, learning equipment. Online learning participants are 30 participants in this activity.

Phase 1: Participant's initial test and initial assessment

After the opening ceremony and before the material was delivered, participants were asked to fill in the questionnaire using google form as a preliminary test. Initial assessment of the participants is done by filling out the online learning registration form.

Phase 2: Submission of online learning material by the instructor

The online learning material consists of presentation regarding character building

The online learning material consists of presentation regarding Human development

The online learning material consists of presentations, brainstorming, and dialogue. The selection of this method is carried out with the aim of achieving the desired targets of successful learning in developing leadership

Phase 3: Post-test and feedback

Before closing, participants are asked to fill in a posttest, and evaluate the event, messages, and impressions of the participants as feedback using google form.

The lecturer on team is assigned to deliver material and assistance, while students play a role to assist 
administration and provide ice breaking. This online learning is carried out in an integrated or combined in a place, because, the online learning method used is discussion and explore the abilities of each participant, making it possible to exchange ideas among fellow participants. This is positive in nature and will certainly invite the attention of the student council officials who have not participated. Hopefully, there will be other students to join in participating in the online learning activities. Th material includes: Participant Expectations, Introduction to Leadership, Management and Organizational Introduction, Problem Solving , and Ice Breaking.

\section{RESULTS AND DISCUSSION}

Leadership is an attempt to influence followers not by force to motivate people to achieve certain goals. The relationship between a leader and a member is related to the degree of emotional quality of the relationship, which includes the level of intimacy and acceptance by the member to the leader. The more confident and trusting the leader members are, the more effective the group is in achieving its goals. Important factors contained in the notion of leadership: (1) the use of influence, (2) human relations, (3) the communication process and (4) the achievement of a goal. Leadership depends on the strength of influence exerted and the intensity of the relationship between the leader and followers.

Community service activities in the form of management and leadership training and development are held with the following objectives: First, to provide students with an understanding of organizational management and leadership. Second, form a leadership character in them from an early age. T Third, as an initial step in the process of intensive coaching students. Fourth, establish OSIS committee who have managerial and creative abilities. Fifth, anticipating students from political objects. Sixth, identifying the political mindset of students and which allowed political activities for students. Based on these objectives, this activity provides benefits in terms of: First, the creation of an independent, creative and efficient student council. Second, it can help stakeholders in managing various activities. Third, improve the existence of schools through student activities. Fourth, the creation of a productive and useful community, especially the OSIS board at the senior high school level.

\section{CONCLUSION}

The process of Building characters who understand management has been instilled in all participants. Building character is not as easy as building houses, bridges, roads, and others because building character is a form of the essence of a person's soul that continues to be better and nobler, building character has many components that must be involved in educational institutions, parents and the community so that it runs ideally. with shared hope. Self-discipline is the most important thing in every effort to build and shape one's character because character implies: a positive quality that a person possesses, which makes him attractive and attractive, one's reputation and someone who is unusual or has an eccentric personality. The stages of forming leadership characters who understand management well are not enough just to carry out one leadership training, but similar and linear learning must be carried out simultaneously. In addition, intensive training is also carried out. This simultaneous regeneration process will continue to be carried out in regeneration every year, so that a cadre culture will be created before the student council committee recruits the student council at school.

The process of creating leadership with character and understanding of management is very necessary and interrelated. The relationship between leadership and management is very close. A close relationship involves cooperation between two or more people, to achieve a predetermined goal. Participatory management is a management approach that involves subordinates in the decision-making process. Active involvement of subordinates by using all their expertise and creativity in solving important management problems. The implementation of participatory management based on mutual authority between superiors and subordinates does not mean that superiors delegate all of their authority or reduce their authority in decision making but involve subordinates in making decisions in solving important management problems.

Leadership is an attempt to influence followers not by force to motivate people to achieve certain goals. The relationship between a leader and a member is related to the degree of emotional quality of the relationship , which includes the level of intimacy and acceptance of members towards the leader. The more confident and believe members of the leader, the more effective groups in achieving goals. Important factors contained in the notion of leadership: (1) the utilization of influence, (2) human relationships, (3) the process of communication and (4) the achievement of a goal. Leadership depends on the strength of influence given and the intensity of the relationship between the leader and followers.

After the online learning is carried out, it is necessary to provide intensive coaching. The problems discussed at the time of learning are problems that are being faced by each student council committee and together seek solutions. This guidance was also carried out by involving several student councils to gather with more advanced learning methods to provide input to other schools. In this case the student council is considered established. The formation of OSIS is due to the relatively functioning regeneration process every year with training held by the school every year. This OSIS Organizational Leadership and Management Online learning will produce a generation that is ready to lead OSIS as OSIS cadre and ready to become leaders in the community and at the organizational level at the university later. 


\section{REFERENCE}

Arief, H., Soelton, M., Rohman, F., \& Ritonga, R. (2019). DEVELOP LEADERSHIP, MANAGEMENT AND PERFORMANCE ORGANIZATION ON INTRA-SCHOOL STUDENT ORGANIZATION (OSIS). ICCD, 2(1), 341 - 344.

Desianty, Sovyia. 2005. Pengaruh Gaya Kepemimpinan Terhadap Komitmen Organisasi Pada PT. Pos Indonesia Semarang. Jurnal Studi Manajemen dan Organisasi, 2(1):69-84.

Lussier N Robert (2010), Human Relation in Organization Applications and Skill Building. New York: Mc. Graw Hill.

Robbins, Stephen P. dan Timothy A. Judge. 2015. Perilaku Organisasi, Edisi 16. Jakarta: Salemba Empat.

Roya Yousefi. (2014), The Effect Of Knowledge Management On Organizational Learning And Performance Of Education Department Of Abhar County. Kuwait Chapter of Arabian Journal of Business and Management Review Vol 3. No.12a; August. 2014.

Soelton, Mochamad, Nugrahati, Tati, 2018. How Complaining Behaviors Effect on Coping Stress and Anxiety?. International Journal of Saudi Journal of Business and Management Studies (SJBMS). Vol. 3, No. 6. 623-628.
Soelton et al, 2019. Gender : Stress Levels On Performance In Modern Industry. International Journal Archives of Business Research (United Kingdom). Vol. 7, No 2. $72-81$

Soelton et al, 2018. Toward The Best Strategy In Minimizing The Spread of Drug Users. International Conference On Community Development In Asia. Vol 1. No 1. 171-176

Tama Putra Saratian, Eko \& Arief, Harefan. (2018). ENTREPRENEURIAL OPPORTUNITIES IN INDONESIA TO INITIATE BUSINESS THROUGH IMPORTER COMMUNITIES. ICCD. 1. 446-454. 10.33068/iccd.Vol1.Iss1.66.

Windhiyana, E. (2020). DAMPAK COVID-19 TERHADAP KEGIATAN PEMBELAJARAN ONLINE DI SEBUAH PERGURUAN TINGGI KRISTEN DI INDONESIA. Perspektif Ilmu Pendidikan, 34(1), 1 - 8.

Yousef, Darwis A. (2012). Organizational Commitment: A Mediator of the Relationship of Leadership Behavior with Job Satisfaction and In a Non Western Country, Journal of Managerial Psychology, Vol. 15 (4): 6-28. 